European Journal of Accounting, Auditing and Finance Research

Vol.8, No. 7, pp.33-41, July 2020

Published by $\boldsymbol{E C R T D}-\boldsymbol{U K}$

Print ISSN: 2053-4086(Print), Online ISSN: 2053-4094(Online)

\title{
ACCOUNTING IMPLICATIONS OF OIL PRICE, INTEREST RATE AND UNEMPLOYMENT ON NIGERIA'S ECONOMIC GROWTH
}

\author{
Dr. Preye E. G. Angaye \\ Head, Business Strategy, Century Group, Ibukun House, \\ Block 105, No 8 Baderinwa Alabi Street, Lekki Phase 1, \\ Lagos State, Nigeria \\ Bingilar Paymaster Frank, PhD. \\ Department of Accounting \\ Faculty of Management Sciences \\ Niger Delta University, Wilberforce Island, Bayelsa State.
}

\begin{abstract}
Holding other variables constant, exchange rate and unemployment are supposed to have an inverse relationship. Is this really the case in the Nigerian economy? Does oil price have an impact on unemployment in Nigeria? Our study analyzed the accounting implications of oil price, interest rate and unemployment on Nigeria's economic growth using data from 1981 to 2019. Using ARDL and VEC models, our finding revealed that all variables had a short and long term association and were statistically significant, hence we recommended better economic policies should be put in place by government to curb unemployment because this has a long and short run implication on GDP, and that if not properly managed can lead to economic and social vices. The government should formulate policies that are economically friendly in order to encourage local production to boost our export and improve our local currency (Naira) and the exchange rate. This will increase local production and firms will create employment opportunities for our teeming population. Increased oil price has really helped in boosting our GDP. However, the economy should be diversified because any drop in oil price will definitely affect our GDP drastically, both in the short and long run.
\end{abstract}

KEYWORDS: efficient wage model, unemployment, interest rate, oil price, accounting implication, gross domestic product, and economic policy.

\section{INTRODUCTION}

The number one priority of any government of the world is to improve her economy and Nigeria is not left out. This cannot be done without sufficient fund. Prior to the discovery of crude oil in commercial quantity in 1958 in Nigeria, Nigeria's major source of revenue was from agriculture which was also a major source of income and employment for her population. Crude oil income contributes over $70 \%$ of government revenue and $95 \%$ of foreign exchange earnings (Odusola, 2006). Nigeria is the largest oil producing country in Africa and the eleventh in the world (Khadijat \& Taophic, 2018). Meanwhile, contrary to the expectations of the positive effect of rising oil prices to economic growth of Nigeria, unemployment has been on the rise. Unemployment is one of the major macroeconomic problems that every economy is trying to reduce to an acceptable level, 
European Journal of Accounting, Auditing and Finance Research

Vol.8, No. 7, pp.33-41, July 2020

Published by ECRTD-UK

Print ISSN: 2053-4086(Print), Online ISSN: 2053-4094(Online)

because if it is not properly managed it could have other negative social and economic outcomes. Hence, every government of the world tries to put measures and policies in place that help in the reduction of the unemployment rate (Ahmad, 2013).

Doğrul and Soytas (2010) studied Turkey's economy from 2005-2009 and revealed that oil price and interest rate improved the forecasts of unemployment in the long run. However, Ahmad (2013) in studying the Pakistani economy revealed that interest rate had no influence on unemployment. This has prompted us to delve into the research due to the contrary views. The surge in the price of oil drastically affects any economy that so depends on oil as a major source of revenue and Nigeria is not left out. To the best of our knowledge from literature reviewed thus far, the accounting implication of oil price, interest rate and unemployment have not been applied to the Nigerian economy using recent data -1991 to 2019. Mellquist and Femermo (2007) in their study of the Swedish economy with respect to the oil price and unemployment using the Granger Causality could not assert whether an increase in the price of oil will lead to a positive or negative impact on unemployment. Karlsson, $\mathrm{Li}$ and Shukur (2018) asserted that the top 20 major oil exporters include Saudi Arabia, Russia, Iran, United Arab Emirates, Kuwait, Nigeria, Iraq, Norway, Angola, Venezuela, Algeria, Qatar, Canada, Kazakhstan, Mexico, Brazil, Colombia, and the United Kingdom. Most of these countries have fixed exchange rates and Nigeria was not left out until 2016 when she adopted a floating exchange rate.

Unemployment in Nigeria has been on the rise despite the macroeconomic policies put in place by government and with the current floating exchange rate and surge in oil price we have deemed it necessary to ascertain the accounting implication on the economy. Nigeria is a country that has a population of more than 180 million people, and well-endowed with crude oil which ought to have made her prosperous and engaged the teeming populace that have the required acumen and are willing and able to work. Looking at the values of the natural resources and the generated revenue, it is expected that the inflows from the oil ought to have been sufficient enough to provide an enabling industry and working environment for the populace (Manasseh et al., 2019).

The rest of this paper is arranged as follows: section two - review of related literature, section three discussed the methodology and the fourth section discussed the presentation of data, data analysis, and test of hypotheses and discussion of findings. While section five contains the conclusion and recommendations.

\section{REVIEW OF RELATED LITERATURE}

\section{Theoretical Framework}

Uri (1996) argued that oil price and exchange rate can affect the productivity of any economy and in turn affect unemployment. This does not only affect manufacturing and agriculture dependent economies but also affects economies like Nigeria that her major source of revenue comes from crude oil sales. Löschel and Oberndorfer (2009) noted that until real wages drop by the same proportion as labour productivity, firms will continue to lay off workers, which will lead to a rise in unemployment and cause a further loss to the economic growth of a nation. With the adoption of the floating exchange rate, increase in the rate will help to reduce unemployment although that of the Nigerian economy has been the reverse as shown below. 


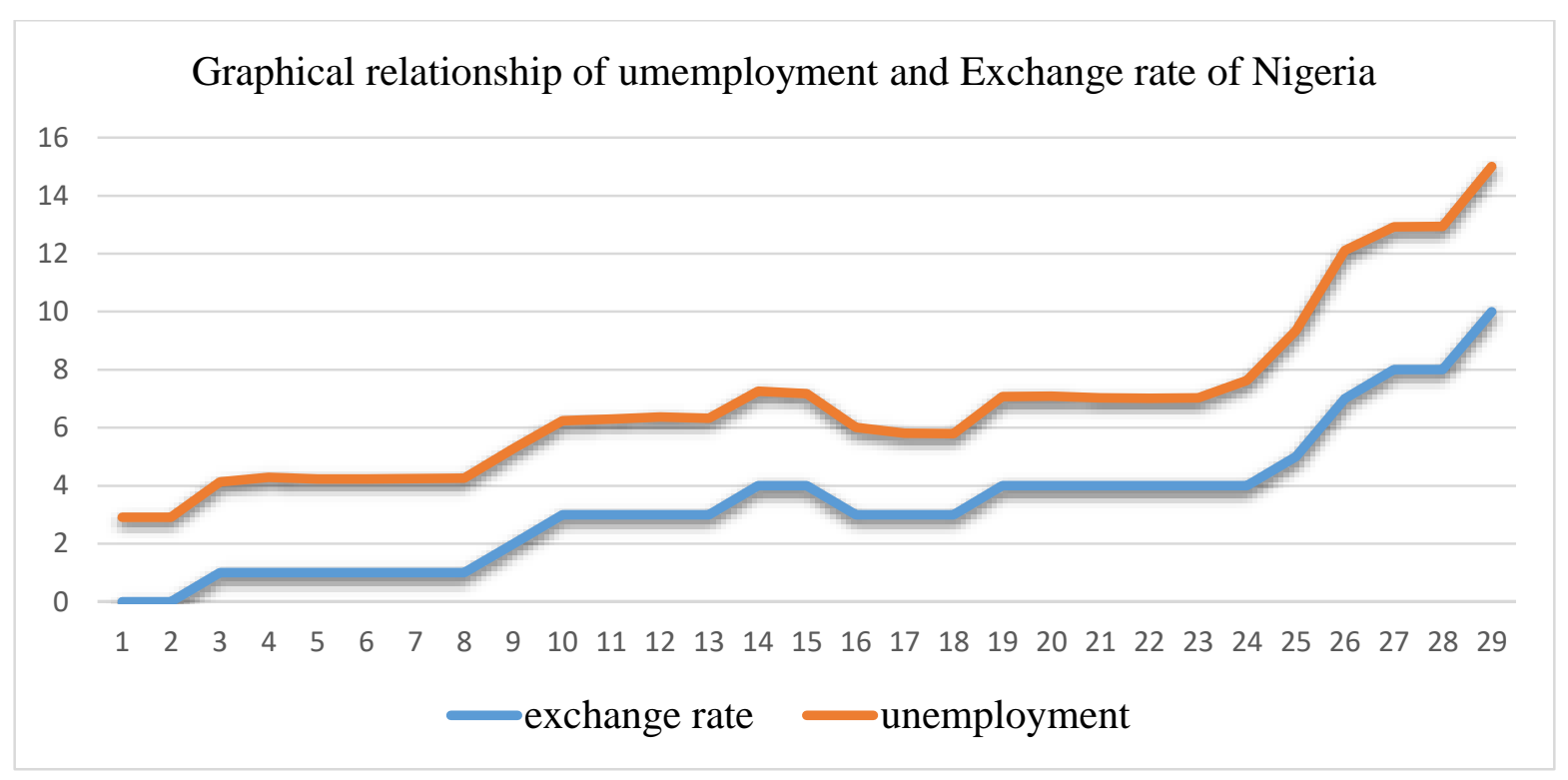

Source: Researchers' computations from statistical bulletin

\section{Unemployment Theory}

Keynes (1936) opined that in order to reduce unemployment, government must provide an enabling environment and provide social and economic policies that will engage the populace productively. His study further revealed that there is an inverse relationship between unemployment and inflation.

Looking at the demand and supply framework of unemployment, it can be deduced that the level of employment depends on factors of production such as labour, wages, price level, and prices of other factors of production. On a broad economic level (macro), unemployment rate is also influenced by the local factors such as economic state, business cycles, the technology level, and population demographics, as well as global factors which are the external factors beyond the control of the employer of labour (Doğrul \& Soytas, 2010).

\section{Exchange rate theory}

Exchange rate plays a great role in an economy (Akujinma, Chijindu and Theodora, 2017). The life-wire of any economy is determined by the exchange rate policy put in place and Nigeria is no different. With the introduction of the Structural Adjustment Programme (SAP) in 1986, our local currency lost value in the international market. Prior to the introduction and adoption of SAP which made use of the floating exchange rate, in the Sixties and Seventies, the fixed exchange rate was used by the regulatory system. Akujinma, Chijindu and Theodora (2017) cited Cassel (1981) who propounded the purchasing power parity (PPP) theory, as a result of the failure of the fixed exchange rate system. The PPP states that the forces of demand and supply of the market should determine the prevailing exchange rate. 
European Journal of Accounting, Auditing and Finance Research

Vol.8, No. 7, pp.33-41, July 2020

Published by ECRTD-UK

Print ISSN: 2053-4086(Print), Online ISSN: 2053-4094(Online)

\section{Empirical studies}

Manasseh et al. (2019) used time series data from 1981 to 2014 to investigate the impact of oil price fluctuation and oil revenue on the well-being in Nigeria. Using multiple regression techniques revealed that oil price fluctuations have no significant impact on well-being, while oil revenue is observed to have a significant and positive impact on well-being. There is a long term relationship between the variables, therefore if any of the variables increases so does the other.

Bassey et al. (2016) examined the relationship between unemployment and monetary policy in Nigeria. They used data from 1983 to 2014. Vector Autoregression (VAR) model was used to analyze the data which found out that a positive shock to policy rate raises unemployment over a 10-quarter period. Hence their study concluded that there is a relationship between monetary policy and unemployment in Nigeria.

Ahmad (2013) used data ranging from 1991 to 2010 of the Pakistani economy to investigate the relationship between oil prices and unemployment. Making 238 observations of each variable for analysis and employed Toda Yamamoto Causality Test revealed a significant impact of oil prices on unemployment but found no significant relationship between real interest rate and unemployment.

Löschel and Oberndorfer (2009) analyzed oil price impacts on unemployment of the German economy. Their data covered from 1973 to 2008, using a Vector Autoregression (VAR) and revealed that oil price increases help increase unemployment in the German labor market. However, this is contrary to the findings of Manasseh et al. (2019).

\section{METHODOLOGY}

\section{Data source}

We used the Vector Autoregression (VAR) to address accounting implications of oil price, interest rate and unemployment on Nigeria's economic growth, which is more recently employed in literature. This is because the model is useful in analyzing financial time series as well as for forecasting. The data employed in this study are Real Gross Domestic Product (GDP), Exchange Rate (EXR), Oil Price (OILP) and Unemployment Rate (UNE).

\section{Econometric model (ARDL)}

The model for this study is restated below:

$\mathrm{GDP}=f(\mathrm{EXR}, \mathrm{OILP}, \mathrm{UNE})$

In order to agree with our Autoregressive distribution lag (ARDL) model, another equation is stated below:

$\Delta \mathrm{Y}_{\mathrm{t}}=\beta_{0}+\sum_{i=1}^{n} \beta \mathrm{i} \Delta \mathrm{y}_{\mathrm{t}-\mathrm{I}}+\sum_{i=0}^{n} \delta \mathrm{i} \Delta \mathrm{X}_{\mathrm{t}-\mathrm{I}}+\Phi_{1} \mathrm{y}_{\mathrm{t}-1}+\Phi_{2 \mathrm{X}_{\mathrm{t}-1}}+\mu_{\mathrm{i}} \ldots \ldots \ldots \ldots .2$

Where:

Short-run

Long -run 
European Journal of Accounting, Auditing and Finance Research Vol.8, No. 7, pp.33-41, July 2020 Published by ECRTD-UK

Print ISSN: 2053-4086(Print), Online ISSN: 2053-4094(Online)

Short-run coefficients: $\beta_{0}, \delta \mathrm{i}$

Long-run coefficients: $\Phi_{1}, \Phi_{2}$

Disturbance (White noise) term: $\mu_{\mathrm{i}}$

\section{THE ERROR CORRECTION MODEL}

$\mathrm{ECM}=\Delta \mathrm{Y}_{\mathrm{t}}=\beta_{0}+\sum_{i=1}^{n} \beta \mathrm{i} \Delta \mathrm{y}_{\mathrm{t}-\mathrm{i}}+\sum_{i=0}^{n} \delta \mathrm{i} \Delta \mathrm{X}_{\mathrm{t}-\mathrm{i}}+\Phi \mathrm{Z}_{\mathrm{t}-1}+\mu_{\mathrm{i}} \ldots \ldots \ldots . .3$

Where: $\mathrm{Z}_{\mathrm{t}-1}=\mathrm{y}_{\mathrm{i}-1}-\mathrm{b}_{0}+\mathrm{b}_{1} \mathrm{x}_{\mathrm{t}-1}$ are the lagged residuals.

\section{DATA PRESENTATION AND ANALYSIS}

\section{Descriptive statistics}

\begin{tabular}{lcccc} 
& GDP & EXR & OILP & UNE \\
\hline Mean & 34664165 & 95.53026 & 48.13667 & 4.113333 \\
Median & 23688280 & 101.7000 & 40.76000 & 3.950000 \\
Maximum & 70354216 & 361.0000 & 109.4500 & 6.240000 \\
Minimum & 13779255 & 0.620000 & 12.28000 & 3.420000 \\
Std. Dev. & 20189072 & 96.41795 & 29.61875 & 0.752135 \\
Skewness & 0.669514 & 0.957833 & 0.653477 & 1.940672 \\
Kurtosis & 1.870775 & 3.339030 & 2.249708 & 5.581713 \\
& & & & \\
Jarque-Bera & 4.985731 & 6.150167 & 3.690482 & 35.31138 \\
Probability & 0.082673 & 0.046186 & 0.157987 & 0.000000 \\
Sum & $1.35 \mathrm{E}+09$ & 3725.680 & 1877.330 & 160.4200 \\
Sum Sq. Dev. & $1.55 \mathrm{E}+16$ & 353264.0 & 33336.27 & 21.49687 \\
Observations & 3 & & & 39 \\
\hline Source: Authors & 39 & 39 & 39 & \\
\hline
\end{tabular}

Source: Authors' computations using eview $10^{+}$ 
European Journal of Accounting, Auditing and Finance Research

Vol.8, No. 7, pp.33-41, July 2020

Published by ECRTD-UK

Print ISSN: 2053-4086(Print), Online ISSN: 2053-4094(Online)

\section{LAG SELECTION CRITERIA}

VAR Lag Order Selection Criteria

Endogenous variables: D(GDP)

Exogenous variables: C D(EXR) D(OILP) D(UNE)

Date: 06/23/20 Time: 21:35

Sample: 19812019

Included observations: 30

\begin{tabular}{cccllll}
\hline \hline Lag & LogL & LR & FPE & AIC & SC & HQ \\
\hline \hline 0 & -465.3001 & NA & $2.27 \mathrm{e}+12$ & 31.28667 & 31.47350 & 31.34644 \\
1 & -455.0168 & $17.13883^{*}$ & $1.22 \mathrm{e}+12^{*}$ & $30.66779^{*}$ & $30.90132^{*}$ & $30.74249^{*}$ \\
2 & -454.9630 & 0.086122 & $1.31 \mathrm{e}+12$ & 30.73086 & 31.01110 & 30.82051 \\
3 & -454.8251 & 0.211418 & $1.39 \mathrm{e}+12$ & 30.78834 & 31.11528 & 30.89293 \\
4 & -453.7316 & 1.603754 & $1.39 \mathrm{e}+12$ & 30.78211 & 31.15576 & 30.90164 \\
5 & -453.7230 & 0.011984 & $1.49 \mathrm{e}+12$ & 30.84820 & 31.26856 & 30.98268 \\
6 & -453.3006 & 0.563253 & $1.56 \mathrm{e}+12$ & 30.88671 & 31.35377 & 31.03613 \\
7 & -453.0667 & 0.296252 & $1.66 \mathrm{e}+12$ & 30.93778 & 31.45155 & 31.10214 \\
8 & -453.0480 & 0.022479 & $1.79 \mathrm{e}+12$ & 31.00320 & 31.56368 & 31.18250 \\
\hline \hline
\end{tabular}

Source: Authors' computations using eview $10^{+}$

* indicates lag order selected by the criterion

LR: sequential modified LR test statistic (each test at 5\% level)

FPE: Final prediction error

AIC: Akaike information criterion

SC: Schwarz information criterion

HQ: Hannan-Quinn information criterion

The above showed that the variables all settle for one lag, which is used in our analysis.

\section{SERIAL CORRELATION}

Breusch-Godfrey Serial Correlation LM Test:

Null hypothesis: No serial correlation at up to 1 lag

\begin{tabular}{llll}
\hline \hline F-statistic & 0.310305 & Prob. F(1,12) & 0.5877 \\
Obs*R-squared & 0.857036 & Prob. Chi-Square(1) & 0.3546 \\
\hline \hline
\end{tabular}

Source: Authors' computations using eview $10^{+}$

The above showed that there is no serial correlation. The value associated with the Chi-Square statistic (0.3546) is more than $5 \%$. 
European Journal of Accounting, Auditing and Finance Research

Vol.8, No. 7, pp.33-41, July 2020

Published by $\boldsymbol{E C R T D}-\boldsymbol{U K}$

Print ISSN: 2053-4086(Print), Online ISSN: 2053-4094(Online)

\section{STABILITY ANALYSIS}

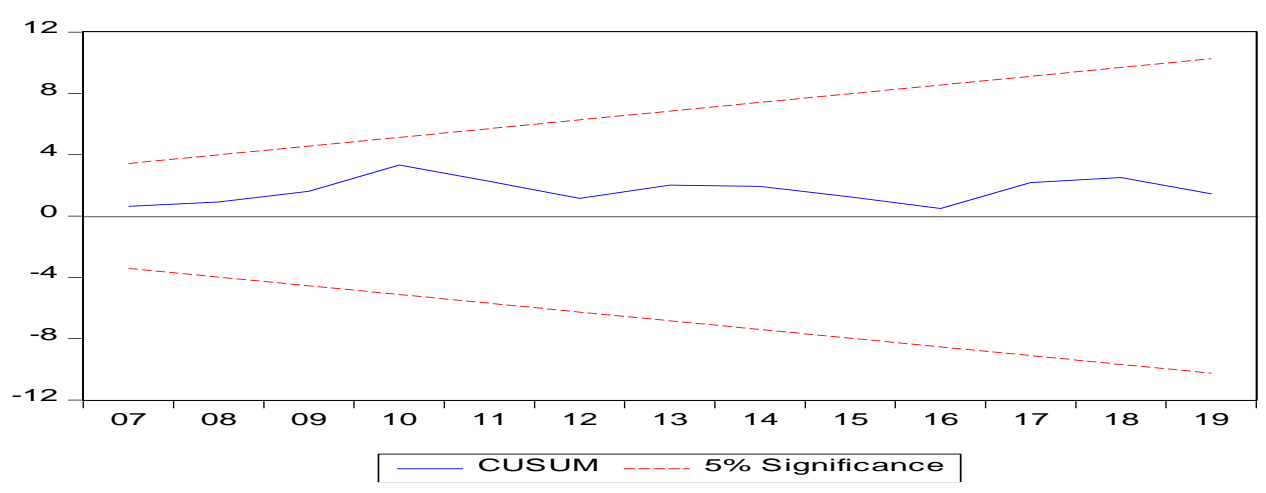

The above showed that our model is stable, since the above line is within the bound region.

BOUND TEST

\begin{tabular}{llll} 
Test Statistic & Value & df & Probability \\
\hline \hline F-statistic & 8.454323 & $(3,23)$ & 0.0006 \\
Chi-square & 25.36297 & 3 & 0.0000 \\
\hline
\end{tabular}

Source: Authors' computations using eview $10^{+}$

The Pesaran table (unrestricted intercept and no trend) at 5\% lower bound 4.94 and upper bound 5.73 with respect to our F-statistic showed that there is a long term relationship between our variables and our model is significant.

\section{ERROR CORRECTION MODEL (ECM)}

Dependent Variable: D(GDP)

Method: Least Squares

Date: 06/22/20 Time: 16:04

Sample (adjusted): 19852019

Included observations: 35 after adjustments

\begin{tabular}{lllll}
\hline \hline Variable & Coefficient & Std. Error & t-Statistic & Prob. \\
\hline \hline C & 40975.06 & 260185.4 & 0.157484 & 0.8764 \\
D(GDP(-1)) & 1.144879 & 0.324956 & 3.523178 & 0.0020 \\
D(EXR(-1)) & 12613.68 & 11570.26 & 1.090181 & 0.2880 \\
D(OILP(-1)) & 14938.74 & 11525.93 & 1.296098 & 0.2090 \\
D(UNE(-1)) & 273001.3 & 842089.9 & 0.324195 & 0.7490 \\
ECT(-1) & -0.905637 & 0.398109 & -2.274846 & 0.0335 \\
\hline \hline
\end{tabular}

Source: Authors' computations using eview $10^{+}$ 
European Journal of Accounting, Auditing and Finance Research

Vol.8, No. 7, pp.33-41, July 2020

Published by $\boldsymbol{E C R T D}-\boldsymbol{U K}$

Print ISSN: 2053-4086(Print), Online ISSN: 2053-4094(Online)

Our correction term (ECT) is the speed of adjustment to equilibrium, which is -0.905637 and statistically significant at 0.0335 .

\section{ECM (SERIAL CORRELATION)}

Breusch-Godfrey Serial Correlation LM Test:

Null hypothesis: No serial correlation at up to 1 lag

\begin{tabular}{llll}
\hline \hline & & & \\
F-statistic & 0.896143 & Prob. F $(1,18)$ & 0.3564 \\
Obs*R-squared & 1.565013 & Prob. Chi-Square (1) & 0.2109 \\
\hline \hline
\end{tabular}

Source: Authors' computations using eview $10^{+}$

The above showed that there is no serial correlations among the variables used in the analysis.

\section{ECM (STABILITY ANALYSIS)}

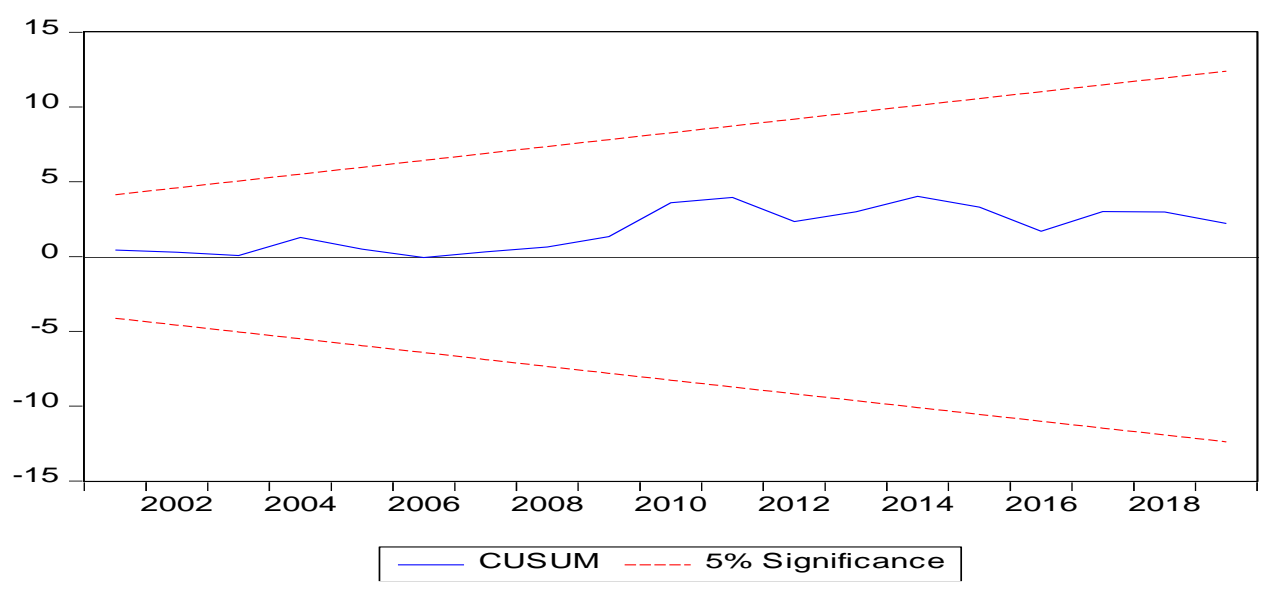

The above showed that our model is stable, since the above line is within the bound region.

\section{CONCLUSION AND RECOMMENDATIONS}

The study analyzed accounting implications of oil price, interest rate and unemployment on Nigeria's economic growth using data from 1981 to 2019 Indexmundi and statistical bulletin of Nigeria by employing the ARDL model and ECM. Our findings revealed there is a long and short run relationship between our variables, which implies that exchange rate, oil price and unemployment have a great impact on our GDP.

Therefore, we recommended that:

a. Better economic policy should be put in place by government to curb unemployment because this has a long and short run implication on GDP, and if not properly managed can lead to economic and social vices; 
European Journal of Accounting, Auditing and Finance Research

Vol.8, No. 7, pp.33-41, July 2020

Published by ECRTD-UK

Print ISSN: 2053-4086(Print), Online ISSN: 2053-4094(Online)

b. The government should formulate policies that are economically friendly in order to encourage local production to boost our exports and improve our local currency (Naira) and the exchange rate. This will increase local production and firms will create employment opportunities for our teeming population; and

c. Increase in the oil price has really helped in boosting our GDP. However, the economy should be diversified because any drastic drop in our oil price will definitely affect our GDP both in the short and long run.

\section{References}

Ahmad, F. (2013). The Effect of Oil Prices on Unemployment: Evidence from Pakistan. Business and Economics Research Journal, 4(1), 43-57.

Akujinma, A. F., Chijindu, A. A., \& Theodora, O. N. (2017). Exchange rate policy and Nigeria's economic growth: a granger causality impact assessment. International Journal of Applied Economics, Finance and Accounting, 1(1), 1-13.

Bassey, K. J., Sunday N. E., Garba A. M., Mary O. A. A., , Suleiman, F. O., Deborah G. O., \& Francisca O. (2016). Monetary Policy and Unemployment in Nigeria: Is there a Dynamic Relationship? Journal of Applied Statistics, 7(1).

Doğrul, G. H., \& Soytas, U. (2010). Relationship between oil prices, interest rate, and unemployment: Evidence from an emerging market. Energy economics, 32, 1523-1528.

Karlsson, K. H., Li, Y., \& Shukur, G. (2018). The Causal Nexus between Oil Prices, Interest Rates, and Unemployment in Norway Using Wavelet Methods. https://www.mdpi.com/2071$1050 / 10 / 8 / 2792 /$ pdf, June, $23^{\text {rd }} 2020$.

Keynes, M. J. (1936). The General Theory of Employment, Interest and Money. https://www.files.ethz.ch/isn/125515/1366_KeynesTheoryofEmployment.pdf, June, 23 ${ }^{\text {rd }}$ 2020.

Khadijat A. Y., \& Taophic O B. (2018). Effect of petroleum profit tax and companies income tax on economic growth in Nigeria. Journal of Public Administration, Finance and Law.

Löschel, A. \& Oberndorfer, U. (2009). Oil and Unemployment in Germany. Centre for European Economic research.

Manasseh, O. C., Abada, C. F., Ogbuabor, E. J., Okoro, U.E., Egele, E. A. \& Ozuzu, C. K. (2019). International Journal of Energy Economics and Policy. International Journal of Energy Economics and Policy, 9(1), 346-355.

Manasseh, O. C., Felicia C. A., Jonathan E. O., Okoro E. U. O., Aja, E. E., \& Kenneth C. O. (2019). Oil Price Fluctuation, Oil Revenue and Well-being in Nigeria. International Journal of Energy Economics and Policy, 9(1), 346-355.

Mellquist, H., \& Femermo, M. (2007). The Relationship between the Price of Oil and Unemployment in Sweden.

https://www.diva-portal.org/smash/get/diva2:4683/FULLTEXT01.pdf, June, $23^{\text {rd }} 2020$.

Odusola, A. (2006). Tax Policy Reforms in Nigeria. World Institute for Development Economics and Research, 3.

Uri, N. D. (1996). Changing crude oil price effects on US agricultural employment, Energy Economics, 18 (3), 185-202. 